\title{
"The Early Urbanism in Europe: The Case of the Trypillia Megasites" Project - The ADS (York) Archive is Soon to Open
}

\author{
John Chapman*, Bisserka Gaydarska, Ray Moore and Louisa Matthews \\ Department of Archaeology, Durham University South Road Durham, UK \\ Submission: August 30, 2018; Published: September 20, 2018 \\ *Corresponding author: John Chapman, Department of Archaeology, Durham University South Road Durham DH1 3LE, UK, \\ Email: j.c.chapman@durham.ac.uk
}

Keywords: Urbanism; Trypillia Megasites; Archive; Palaeo-environment; Fieldwalking; Perimeter; Ditch; Burnt houses; Report; Geophysical; Mega-structure; Assembly Houses; Trial excavations; County; Radius

\section{Opinion}

The "Early urbanism in Europe: the case of the Trypillia megasites" Project was a joint Ukrainian - British Project (2009 2014) co-directed by Mykhalo Videiko (Kyiv) and John Chapman (Durham). The Project fieldwork focussed on the Trypillia megasite of Nebelivka, Novoarkhangelsk Region, Kirovograd County. Our fieldwork efforts included the production of the only so far complete geophysical plan of a megasite (ADS Section 4). Based on this plan, we completed the total excavation of two burnt houses (A9 and B17) (ADS Section 5.2), one unburnt house (TP1/4) (ADS Section 5.2), the Mega-structure (ADS Section 5.1), two pits (B17 and Pit 1, Sondazh 1) (ADS Sections 5.2 \& 5.4) and the industrial structure (ADS Section 5.5).

Figure 1: the Nebelivka plan, divided into Quarters (by Yvonne Beadnell, based upon information from D. Hale, Archaeological Services, Durham University).

A total of 94 test pits (usually $2 \mathrm{~m} \times 1 \mathrm{~m}$, up to $5 \mathrm{~m} \times 1 \mathrm{~m}$ ) was excavated on burnt houses, unburnt houses and Assembly Houses (ADS Section 5.3) to gain a broad architectural sample and produce samples for AMS dating (ADS Section 4.9). Transverse trenches were excavated across three parts of the perimeter ditch (ADS Section 5.6) and the cleaning of a robber's pit in the site barrow produced a buried soil sequence (ADS Section 5.7). Intensive, systematic fieldwalking in the Nebelivka micro-region (5km radius) and targeted fieldwalking in the macro-region ( $25 \mathrm{~km}$ radius) produced the first accurate 
settlement pattern for the Trypillia group, put in the context of the overall Trypillia site distribution (ADS Section 2). Our palaeo-environmental reconstructions included the multi-proxy analysis of the Nebelivka 1B core, molluscan analyses and soil micromorphological analyses (ADS Section 3). An experimental programme included two small-scale experiments in Durham but focussed on the construction of two 4m x 3m 'Trypillia' houses (one 1-storey, the other 2-storey), the burning of the 2-storey house and the excavation of its burnt remains (ADS Section 6).

The publication of such a complex Project necessitated the division of basic data from interpretation - not a division that could readily be supported on theoretical grounds but was more easily made in practical terms of the huge quantity of excavated data (including over 20,000 sherds). As the principal funder, the Arts \& Humanities Research Council has a policy for Projects to deposit their digital data with the Archaeology Data Service, hosted in the University of York. The Project worked with Louisa Matthews and Ray Moore (ADS York) in 2017 and 2018 to structure the data for a Project Archive. The result is that primary material such as photographs, illustrations, specialist reports and data are now available to researchers to download free of charge. The archive supports and complements the forthcoming publication

The Project Archive's DOI is https://doi org/10.5284/1047599: The Archive is divided into six sections (see above): 1 - Introduction; 2 - Trypillia-Cucuteni distribution;
3 - The Palaeo-environment; 4 - the Megasite for the geophysical plan, (Figure 1); 5 - Trial excavations; and 6 - the Experimental Programme. Sections and sub-sections begin with a short 'REPORT' explaining the significance of the research. In the excavation reports in Section 5, there is a summary of the excavation unit, a context sheet, plan(s) and section(s), digitised plans (2012 - 2013), field photos and photogrammetric plans (2014 only). For each excavation unit, the finds are recorded in pottery and Special Finds lists, with photographs and/or drawings of most feature sherds (rims, carinations, decorated sherds and bases) and Special Finds. This Archive includes thousands of colour photographs of all decorated sherds larger than $2 \times 2 \mathrm{~cm}$, for the first time in Trypillia research. All the material in the Archive can be downloaded without a charge but with the responsibility of making an acknowledgement of the source of the material in the case of re-publication.

The Project and ADS hope that this Archive will be of value to all Trypillia researchers and to the wider community of European prehistorians. If you have comments on the Archive, please address them in the first instance to Gaydarska. The second part of the Project publication - the online monograph - will be published by De Gruyter in late 2018 / early 2019 as Gaydarska B. Early urbanism in Europe: the case of the Trypillia mega-sites. De Gruyter. In addition to print-on-demand of this monograph, the entire monograph can be downloaded without charge.

\section{Your next submission with Juniper Publishers will reach you the below assets}

- Quality Editorial service

- Swift Peer Review

- Reprints availability

- E-prints Service

- Manuscript Podcast for convenient understanding

- Global attainment for your research

- Manuscript accessibility in different formats

( Pdf, E-pub, Full Text, Audio)

- Unceasing customer service

Track the below URL for one-step submission https://juniperpublishers.com/online-submission.php 